\title{
Effects of growth hormone on insulin sensitivity and forearm metabolism in normal man
}

\author{
N. Møller, P.C. Butler, M. A. Antsiferov and K.G. M. M. Alberti \\ Department of Medicine, The Royal Victoria Infirmary, Newcastle Upon Tyne, UK
}

\begin{abstract}
Summary. To elucidate the short-term actions of growth hormone on insulin sensitivity and forearm metabolism, we have studied six normal male subjects receiving a 6-h hyperinsulinaemic euglycemic clamp with and without a concomitant 4-h growth hormone infusion. When infused, serum growth hormone rose to $25 \pm 4 \mathrm{mU} / 1$ and during administration of insulin serum insulin increased by $11 \pm 1 \mathrm{mU} / 1$. During euglycemic clamp, administration of growth hormone decreased forearm glucose uptake after $180 \mathrm{~min}$ and onward (240 $\mathrm{min} \quad 0.216 \pm 0.031$ vs $0.530 \pm 0.090 \mathrm{mg} / 100 \mathrm{ml} / \mathrm{min}$, $p<0.05)$. Glucose infusion rate $(240 \mathrm{~min} 2.83 \pm 0.24$ vs $4.35 \pm$ $0.28 \mathrm{mg} \cdot \mathrm{kg}^{-1} \cdot \mathrm{min}^{-1}, p<0.05$ ) and glucose disposal rate (240 min $3.57 \pm 0.17$ vs $4.00 \pm 0.15 \mathrm{mg} \cdot \mathrm{kg}^{-1} \cdot \mathrm{min}^{-1}, p<0.05$ ) also decreased. Growth hormone persistently increased he-
\end{abstract}

patic glucose production after $120 \mathrm{~min}$. After $210 \mathrm{~min}$, all circulating lipid intermediates increased slightly. The decrease in forearm glucose uptake and glucose infusion rate and the increase in hepatic glucose production was observed before there was any detectable increase in circulating levels and forearm uptake of lipid intermediates. These data suggest that growth hormone induces insensitivity to insulin in liver, muscle and fat after 120,180 and 210 min respectively. The early effects of growth hormone on glucose metabolism seems independent of changes in the rate of lipolysis.

Key words: Growth hormone, intermediary metabolism, insulin sensitivity, glucose turnover, non-esterfied fatty acids, ketone bodies and forearm technique.
The actions of growth hormone (GH) on intermediary metabolism are not fully understood [1]. Studies in patients with acromegaly [2] and in normal [3,4] and diabetic [5] man given $\mathrm{GH}$ for various periods of time have shown that sustained elevation of GH-levels is associated with a decrease in glucose sensitivity to insulin, both in the liver and in extrahepatic tissues. The length of time for $\mathrm{GH}$ to exert these actions has not been precisely determined.

In contrast, earlier studies indicated that in the basal state, GH administration induces an early insulin-like effect on glucose metabolism [6,7]; whereas forearm studies have suggested that GH acutely decreases peripheral disposal of glucose $[8,9]$.

Most [9, 10], but not all [3] reports, have shown that in man exogenous $\mathrm{GH}$ augments lipolysis, and there is evidence to support that $\mathrm{GH}$ increases the fraction of non-esterified fatty acids (NEFA) being oxidised to ketone bodies in the liver [11]. It has been proposed that the insulin opposing actions of $\mathrm{GH}$ on glucose turnover could be caused by increased availability of fat intermediates resulting in substrate competition [1].

The present study was undertaken to elucidate the effects of a $4 \mathrm{~h}$ elevation in serum levels of GH on glu- cose turnover and substrate exchange aross the forearm muscles in the insulin stimulated state, with particular reference to the temporal interrelationship between changes in individual metabolites.

\section{Subjects and methods}

\section{Subjects}

Six healthy, normal weight male volunteers (aged $30 \pm 2$ years, body mass index $21.0 \pm 0.7 \mathrm{~kg} / \mathrm{m}^{2}$ ) gave informed consent to participate in the study, which had been approved by the Newcastle upon Tyne Health Authority Ethical Committee.

After an overnight fast of $10 \mathrm{~h}$, subjects attended hospital and were studied sitting comfortably in an armchair. Subjects were studied on 2 occasions in random order and with minimum intervals of 4 weeks: (1) receiving a $6 \mathrm{~h}$ i.v. infusion of insulin (euglycemic clamp); (2) receiving an insulin infusion $(6 \mathrm{~h})$ together with a $\mathrm{GH}$ infusion $(4 \mathrm{~h})$.

\section{Catheter placement}

At 09.00 hours, a catheter was inserted retrogradely into a deep antecubital vein of one arm for sampling of blood derived from the forearm muscles [12]. The criteria for satisfactory positioning were 
Table 1. Substrate uptake in the deep forearm tissues

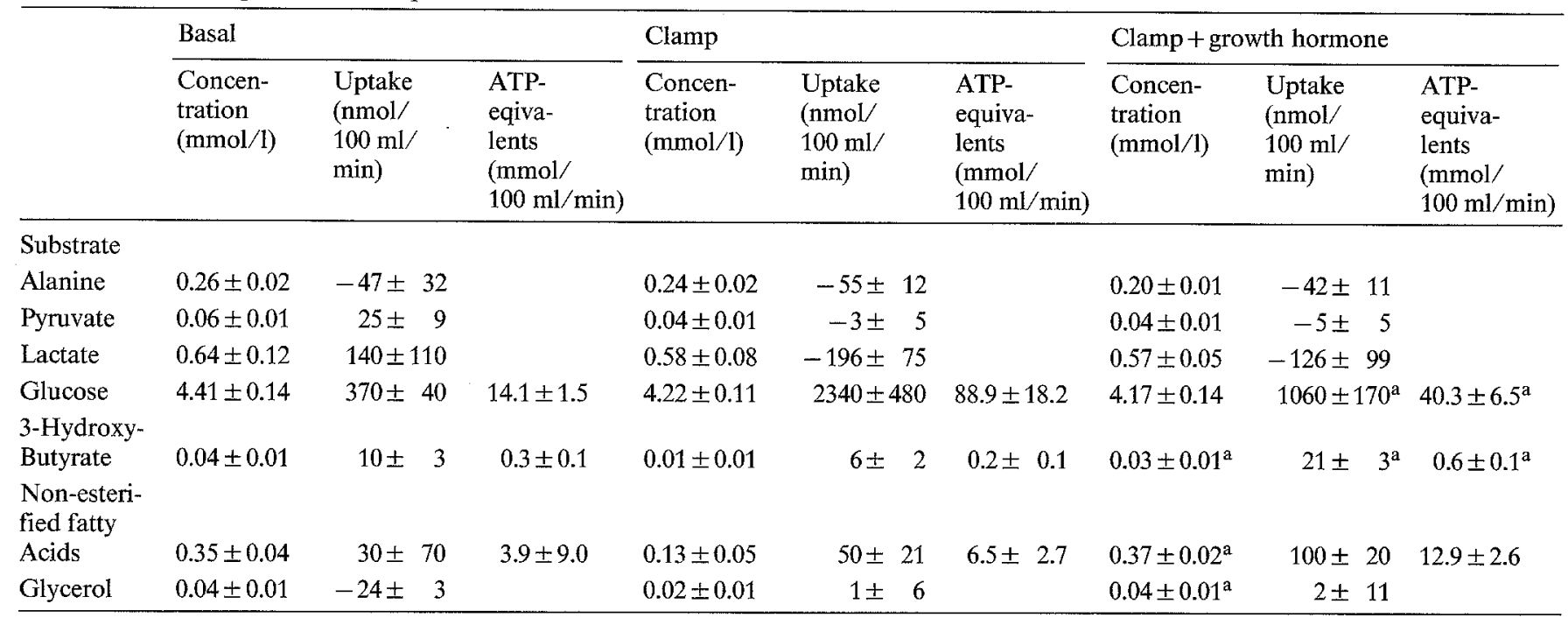

Values are means \pm SEM of arterialised whole blood and are given in the basal post-absorptive state (Basal), at the end of a $6 \mathrm{~h}$ euglycemic clamp (Clamp) and at the end of a combined $6 \mathrm{~h}$ euglycemic clamp and a $4 \mathrm{~h}$ growth hormone infusion (Clamp + growth hormone).

a Values obtained with growth hormone infusion differ significantly from the ones obtained without

that the tip of the catheter could not be palpated, and that the oxygen saturation in blood drawn from the catheter was below $60 \%$ [13]. In the contralateral arm, one catheter was placed retrogradely in a heated dorsal hand vein for sampling of arterialised blood [14], and another catheter was positioned anterogradely into an antecubital vein for infusion of [6-3H]glucose, $\mathrm{GH}$, insulin and glucose. In each individual, the same veins were used for insertion on each occasion. On all occasions, 18-gauge Venflon catheters (Viggo, Helsingborg, Sweden) were used. Oxygen saturation in blood drawn from the heated dorsal hand vein was consistently above $91 \%$.

\section{Sampling intervals}

Two baseline samples were taken at 09.30 and 10.00 hours, and then infusion of $[6-3 \mathrm{H}] \mathrm{glucose}$, insulin and glucose was initiated. Blood samples were then obtained at 5,15 or $30 \mathrm{~min}$ intervals as indicated in the Figures.

\section{The forearm technique}

Preceeding every deep venous sample, total ipsilateral forearm blood flow was determined by means of venous occlusion plethysmography [15]. Hand blood flow was interrupted by a wrist cuff inflated to a pressure of $250 \mathrm{~mm} \mathrm{Hg}$ immediately before every blood flow determination and $1 \mathrm{~min}$ before every deep venous sample. Arterialised and deep venous blood was drawn simultaneously at the time points indicated in the Figures.

Substrate balances across the deep forearm tissues (Table 1) were then calculated as the product of blood flow $(\mathrm{ml} / 100 \mathrm{ml} / \mathrm{min})$ to the tissues drained by the deep forearm vein and change in total blood content (arterialised blood - deep venous blood) of each metabolite across the forearm. For these calculations the following assumptions were made: (1) The relative blood flow $(\mathrm{ml} / 100 \mathrm{ml} / \mathrm{min})$ to the tissues drained by the deep forearm vein equals $0.47 \times$ total forearm blood flow +0.83 [16]. (2) Red cell intracellular NEFA equilibrate freely with plasma NEFA and total blood concentration of NEFA can thus be calculated by multiplying plasma NEFA by $(1-0.30 \times$ hematocrit $)$ (similar to the way in which plasma glucose values are converted to whole blood glucose values [17]). Since all other metabolites were measured on lysed whole blood, no further adjustments were made in these cases. (3) When being catabolised oxidatively the ATP production from one mol of glucose, 3-hydroxybutyrate and NEFA (i.e. palmitate) is 38,30 and $129 \mathrm{~mol}$ of ATP respectively [18]. Since GH did not influence the flux of any other metabolite measured across the deep forearm bed, none of these were included in calculation of the energy balance across the forearm.

\section{Infusions}

On each occasion, [6-3H] glucose (Amersham Ltd., Buckinghampshire, UK) was infused as a bolus of $25 \mu \mathrm{Ci}$ followed by a continous infusion of $15 \mu \mathrm{Ci} / \mathrm{h}$ for $6 \mathrm{~h}$. Two hours were allowed for the isotope to equilibrate. A non-primed infusion of human insulin (Humulin, Eli Lilly, Ind., USA) was started simultaneously at a rate of $0.015 \mathrm{U} / \mathrm{kg} / \mathrm{h}$ to achieve serum insulin levels within the physiological range. Blood glucose was then measured every 5 min (Glucose Analyzer, Yellow Springs Instruments, Yellow Springs, Ohio, USA), and the blood glucose was clamped at a value $0.2 \mathrm{mmol} / 1$ below fasting level (to minimise fluctuations in endogenous insulin secretion) by adjusting a variable infusion of $20 \%$ glucose [19]. During one of the studies, an infusion of biosynthetic human growth hormone (Somatonorm (methionyl-hGH), KabiVitrum, Stockholm, Sweden) was commenced $2 \mathrm{~h}$ after the start of the study at a rate of $4 \mu \mathrm{g} / \mathrm{kg} / \mathrm{h}$ for $30 \mathrm{~min}$ followed by $2.5 \mu \mathrm{g} / \mathrm{kg} / \mathrm{h}$ for $3.5 \mathrm{~h}$. Pituitary and recombinant human GH have been shown to have identical metabolic effects in man [20]. GH and insulin were dissolved in Haemacel (Hoechst, Frankfurt, FRG) before infusion.

\section{Analytical methods}

Blood glucose, 3-hydroxybutyrate, glycerol, alanine, pyruvate and lactate were assayed by automated fluorimetric enzymatic methods [21]. Plasma NEFA was measured by an automated enzymatic method [22]. Radioimmunoassays were employed to measure serum GH [23], insulin [24] and C-peptide [25]. Serum somatomedin-C was assayed using a commercial radioimmunoassay (Incstar Corp., Stillwater, Minn., USA). The specific activity of tritiated glucose was measured as described previously [26]. Briefly this involved depro- 
teinisation with barium hydroxide: zinc sulphate, passage through an anion exchange column, freeze drying and liquid scintillation counting. Recovery standards were prepared with saturated benzoic acid $/ 10 \%$ glucose [27].

The equation of Steele et al. [28] was utilised for calculation of non-steady state glucose appearance/disposal rates $(\mathrm{Ra} / \mathrm{Rd})$. A pool fraction of 0.65 was used. Hepatic glucose output (HGO) was estimated by subtracting the observed infusion rates of glucose (M-value) from the calculated $\mathrm{Ra}$ value. Negative values for $\mathrm{HGO}$ were not modified further. Results are expressed as means \pm SEM. Significance was assessed with ANOVA and where appropriate Student's t-test for paired data. A $p$ value $<0.05$ (two-tailed) was considered statistically significant. Unless specified otherwise concentrations of metabolites or hormones referred to below represent values obtained with arterialised blood.

\section{Results}

The GH infusion increased serum GH from baseline values of $3.2 \pm 1.7 \mathrm{mU} / 1$ to a slightly increasing level of $31.2 \pm 2.8 \mathrm{mU} / 1$ after $4 \mathrm{~h}$ (Fig. 1 ).

Infusion of insulin caused serum insulin to rise from $4 \pm 1 \mathrm{mU} / 1$ to a plateau of $15 \pm 1 \mathrm{mU} / 1$ and serum Cpeptide to drop from a baseline level of $0.40 \pm 5 \mathrm{nmol} / 1$ to $0.21 \pm 4 \mathrm{nmol} / 1 \quad(p<0.01)$ (Fig. 1). Introduction of $\mathrm{GH}$ did not affect either parameters. Basal serum somatomedin- $\mathrm{C}$ values were not affected by insulin or $\mathrm{GH}$ infusions and remained constant around a basal level of $27.2 \pm 2.2 \mathrm{nmol} / 1$.

After administration of insulin plasma NEFA, blood glycerol and 3-hydroxybutyrate values fell from basal levels of $410 \pm 80,39 \pm 6$ and $42 \pm 9 \mu \mathrm{mol} / 1$ to a plateau of approximately $150 \pm 60,20 \pm 5$ and $10 \pm 5 \mu \mathrm{mol} / 1$ respectively (Table 1 ). When $\mathrm{GH}$ was added, all three metabolites rose towards the end of the study period achieving maximum values of $480 \pm 60$ $(p<0.05), 43 \pm 6(p<0.01)$ and $30 \pm 3(p<0.05) \mu \mathrm{mol} / 1$ respectively at $240 \mathrm{~min}$. The increases of these values were statistically significant from $210 \mathrm{~min}$ (NEFA), $180 \mathrm{~min}$ (glycerol) and $240 \mathrm{~min}$ (3-hydroxybutyrate), when compared to insulin administration alone. Only at $240 \mathrm{~min}$ was the forearm uptake of 3-hydroxybutyrate significantly increased; whereas uptake of NEFA was not affected by $\mathrm{GH}$ at any timepoint.

GH administration did not affect any parameters of alanine, pyruvate or lactate metabolism (Table 1). The basal forearm release of alanine remained constant. No consistent pattern of lactate exchange across the forearm was observed until $3 \mathrm{~h}$ into the clamp when a steady release was recorded.

As shown in Figure 2, insulin infusion caused the glucose infusion rate (M-value) to increase steadily to $4.4 \pm 0.3 \mathrm{mg} \cdot \mathrm{kg}^{-1} \cdot \mathrm{min}^{-1}$ at $240 \mathrm{~min}$, the disposal rate for glucose (Rd) to rise to a maximum of $4.0 \pm 0.2 \mathrm{mg} \cdot \mathrm{kg}^{-1} \cdot \mathrm{min}^{-1}$ at $240 \mathrm{~min}$ and HGO to decrease, therefore, to $-0.4 \pm 0.2 \mathrm{mg} \cdot \mathrm{kg}^{-1} \cdot \mathrm{min}^{-1}$ at $240 \mathrm{~min}$. GH administration diminished the $\mathrm{M}$-value by $36 \%\left(2.8 \pm 0.2 \mathrm{mg} \cdot \mathrm{kg}^{-1} \cdot \mathrm{min}^{-1}\right.$ at $\left.240 \mathrm{~min}, p<0.05\right)$ and $\mathrm{Rd}$ by $10 \%\left(3.6 \pm 0.2 \mathrm{mg} \cdot \mathrm{kg}^{-1} \cdot \mathrm{min}^{-1}\right.$ at $240 \mathrm{~min}$,
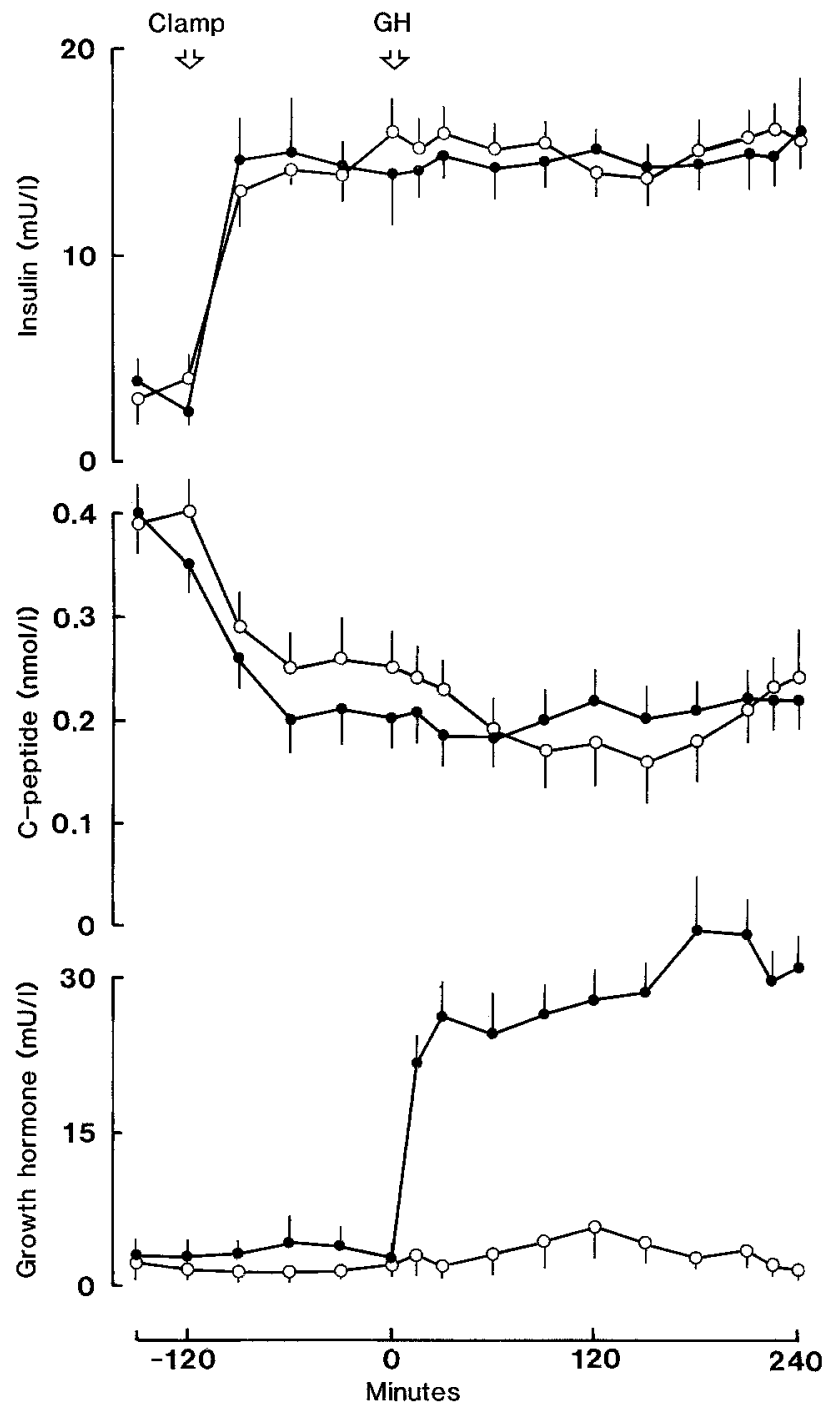

Fig. 1. Mean \pm SEM serum insulin, C-peptide and growth hormone during a $6 \mathrm{~h}$ euglycaemic clamp with and without a $4 \mathrm{~h} \mathrm{GH}$ infusion. - represent values obtained with the $\mathrm{GH}$ infusion and $\mathrm{O}-\mathrm{O}$ control values

$p<0.05$ ). These decrements achieved significance after 180 and $225 \mathrm{~min}$ of $\mathrm{GH}$ administration. $\mathrm{GH}$ caused HGO to rise to $0.7 \pm 0.2 \mathrm{mg} \cdot \mathrm{kg}^{-1} \cdot \mathrm{min}^{-1}$ at $240 \mathrm{~min}$ $(p<0.05)$; this effect on glucose production was significant after $120 \mathrm{~min}$. At the end of the study, GH had decreased forearm glucose uptake by $58 \%$ (with $\mathrm{GH}$ $0.22 \pm 0.03 \mathrm{mg} / 100 \mathrm{ml} / \mathrm{min}$ vs $0.53 \pm 0.09 \mathrm{mg} / 100$ $\mathrm{ml} / \mathrm{min}$ ) (Fig. 3). The decrease was statistically significant $(p<0.05)$ after $180 \mathrm{~min}$ of $\mathrm{GH}$ administration. The clamped values of arterialised blood glucose did not differ statistically at any time.

The effects of the euglycemic clamp alone and togehter with the GH infusion on substrate fluxes recorded across the deep forearm tissues are shown in Table 1. GH caused glucose uptake to decrease and uptake of lipid substrates to increase. Total uptake of ATP equivalents was decreased with $\mathrm{GH}$. 

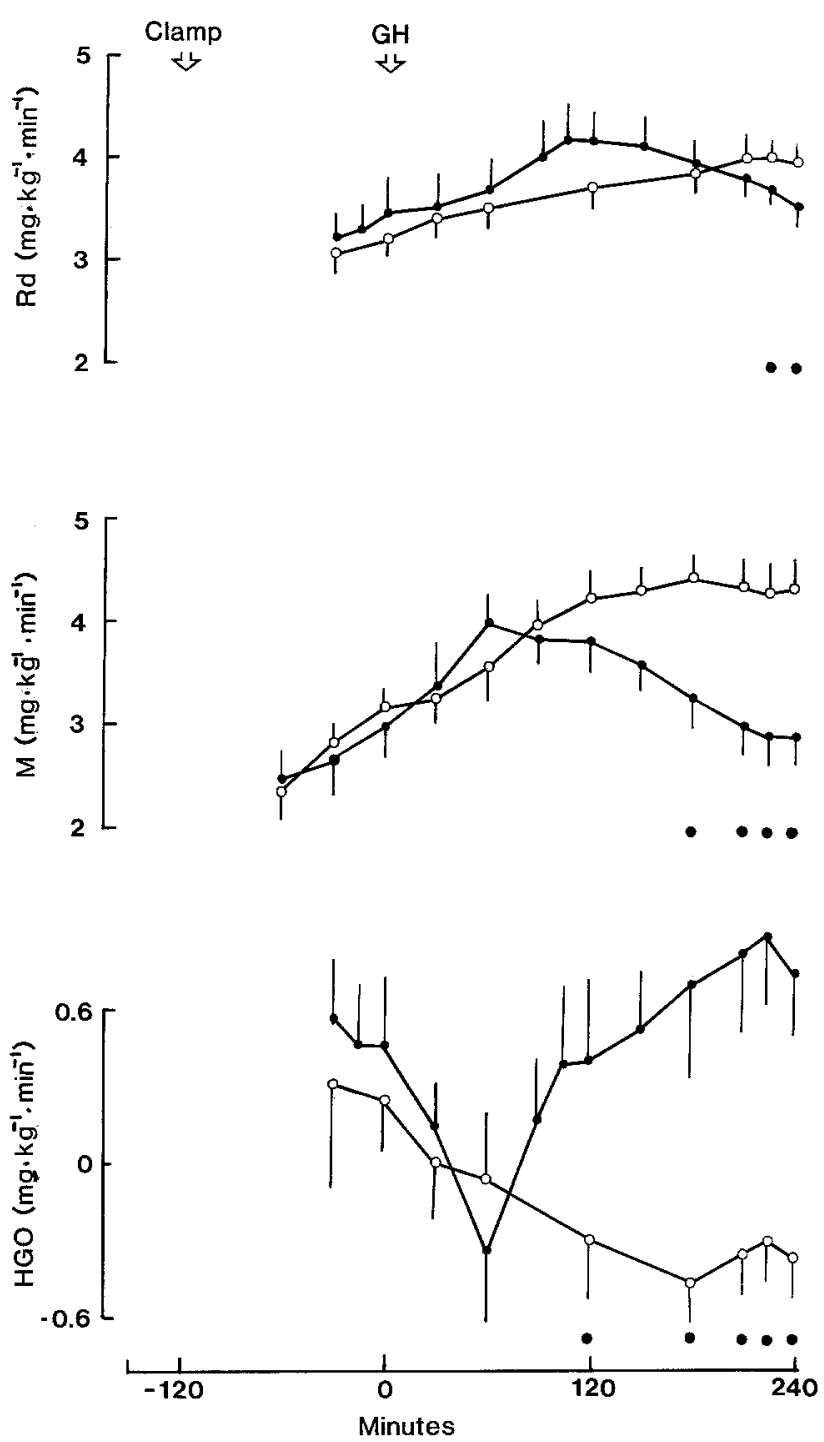

Fig. 2. Mean \pm SEM disposal rate (Rd), infusion rate $(M)$ and endogenous production rate (HGO) for glucose during the euglycemic clamp. ( $p<0.05$ when compared to control values.) Symbols as in Figure 1

Total forearm blood flow did not change in any of the studies but remained constant around a baseline value of $2.4 \pm 0.2 \mathrm{ml} / 100 \mathrm{ml} / \mathrm{min}$.

\section{Discussion}

The present study was designed to examine the effects of a moderate elevation of serum GH levels for $4 \mathrm{~h}$ on glucose turnover and substrate exchange across the deep forearm tissues in the presence of "physiological" hyperinsulineaemia.

Previous studies have shown that GH administration for more than $2 \mathrm{~h}$ impairs hepatic, as well as extrahepatic tissue sensitivity to the actions of insulin on glucose metabolism [3, 4]. Both studies employed

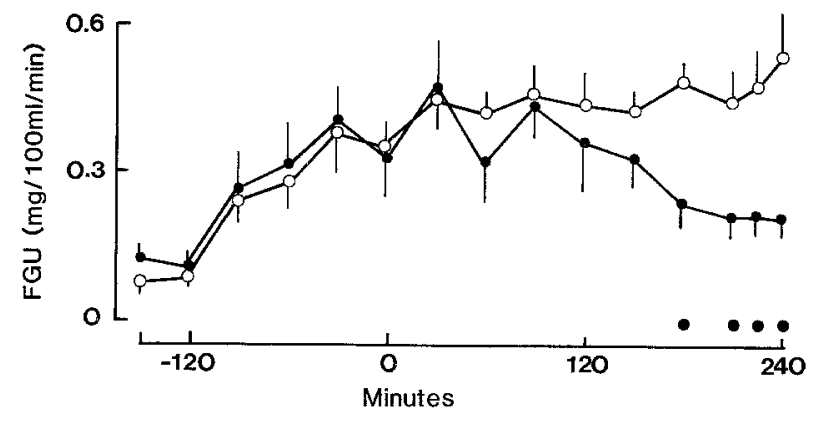

Fig.3. Forearm glucose uptake (FGU) during the euglycemic clamp. GH infusion was commenced at 0 min. Symbols as in Figure 1

relatively high insulin doses achieving insulin levels between 40 and $2400 \mathrm{mU} / 1$. Impairment of insulin sensitivity occured within $2-12 \mathrm{~h}$ of $\mathrm{GH}$ administration. The present data show that, with modest levels of hyperinsulinaemia, overall insulin sensitivity as judged by the M-value is diminished after $3 \mathrm{~h}$. With $\mathrm{GH}$, the M-value started to decrease at least $1 \mathrm{~h}$ earlier (Fig. 2). The failure of one of the above studies [3] to demonstrate insulin insensitivity after $2 \mathrm{~h}$ could relate to the higher dose of insulin employed.

The tracer data indicate that hepatic insulin sensitivity is affected after $2 \mathrm{~h}$ and extrahepatic sensitivity after $3.5 \mathrm{~h}$ of GH exposure. These data should, however, be interpreted with some caution since inadequacy of the isotope dilution technique in its present form, whether caused by a non-steady state error or by isotope discrimination/contamination, may lead to under-estimation of HGO and inability to detect small changes in glucose turnover.

Reports by Bratusch-Marrain et al. [3] and McGorman et al. [7] have suggested that GH, in the basal state, exerts an acute insulin agonistic effect on the liver and hepatic venous catheterisation has indicated that administration of pharmacological GH doses decreases splanchnic glucose output by $35-40 \%$ in man [6]. Our results do not provide any evidence that $\mathrm{GH}$ inhibits HGO during modest hyperinsulinaemia. It is of interest that GH apparently acts as a partial insulin agonist on the liver, i.e. suppresses HGO in the postabsorptive state and increases HGO in the presence of hyperinsulinaemia. In the physiological state, the insulin agonistic action of GH is probably the more important, since significant secretion of GH and insulin very rarely coincides and since secretory bursts of $\mathrm{GH}$ are usually shortlived [29]. Hypothetically, these actions of GH on the liver could be mediated by paracrine actions of somatomedin-C. The latter is an overall insulin agonist but far less potent than insulin itself [30].

It has been estimated that, under conditions of the hyperinsulinaemic euglycemic clamp, skeletal muscle accounts for the major part of glucose disposal [31]. The present data confirm that the major tissue where GH impairs insulin sensitivity to glucose utilisation is 
skeletal muscle; tracer determined glucose disposal was decreased by $10 \%$ and the $\mathrm{M}$-value by $38 \%$; whereas glucose uptake by the forearm was decreased by $58 \%$. It is possible that the decrease in tracer determined disposal is an underestimate of the true events since, with changes in turnover, the tracer requires some time to equilibrate with glucose compartments in the body [32].

During a conventional hyperinsulinaemic euglycemic clamp, the major fate of the glucose taken up by muscle tissue is non-oxidative conversion into glycogen [31,33]; with the more moderate insulin dose employed in the present study, muscular glucose oxidation may, however, be of equal importance, and GH could thus inhibit oxidative as well as non-oxidative utilisation of glucose in muscle.

In the present study, there was a small $20 \%$ increase in blood lactate 60-90 min after initiation of infusion of insulin and glucose; whereafter lactate values decreased towards baseline values (Table 1). No consistent forearm release of lactate was recorded until $3 \mathrm{~h}$ into the clamp, suggesting that the early increase in circulating lactate was due to a release form tissues other than muscle or a decrease in clearance. GH administration did not influence any parameter of lactate metabolism.

GH has been reported not to affect the ability of insulin to suppress plasma levels of NEFA [3]. Our results demonstrate that GH does overcome the anti-lipolytic effects of moderate hyperinsulinaemia. Although minimal, the increase in NEFA, glycerol and 3-hydroxybutyrate was significant after 210,180 and 240 min respectively. Again the inconsistency in results compared to the previous study [3] could relate to the more moderate insulin dose given and the longer clamp-period in the present study. It has been proposed [1] that the ability of GH to inhibit glucose disposal is dependent on increased availability of competing substrates (NEFA, ketone bodies), a concept put forward by Randle et al. [34]. The present study, however, shows that during hyperinsulinaemic euglycemia decreased glucose disposal in the forearm is found before there is any detectable increase in either circulating levels of, or net uptake of alternative fuels. This finding is in agreement with one earlier study in the basal state [9]; whereas Rabinowitz et al. [8] employing supraphysiological and possibly contaminated GH doses found an early increase in forearm uptake of NEFA. Unless GH induces an increase in local or intra-myocytic release and utilisation of NEFA, our data strongly suggests that GH has independent actions to decrease peripheral (i.e. muscular) glucose uptake. Only with more sustained elevations of $\mathrm{GH}$, as seen in many pathological states, is the glucose/fatty acid/ketone body cycle likely to achieve increasing significance in the pathogenesis of peripheral insulin insensitivity.

As the observed changes in lipid intermediates are unlikely to play any role in the early impairment of glu- cose sensitivity to insulin and as short term infusion of $\mathrm{GH}$ has been shown not to interfer with insulin receptor binding $[3,4]$, modulation of post-receptor events (i.e. enzymes) represents the most likely mechanism, whereby $\mathrm{GH}$ acutely impairs glucose disposal.

\section{References}

1. Davidson MB (1987) Effect of growth hormone on carbohydrate and lipid metabolism. Endocr Rev 8: 115-131

2. Hansen I, Tsalikian E, Beaufrere B, Gerich J, Haymond M, Rizza $R$ (1986) Insulin resistance in acromegaly: defects in both hepatic and extrahepatic insulin action. Am J Physiol 250: E269-E273

3. Bratusch-Marrain PR, Smith D, DeFronzo RA (1982) The effect of growth hormone on glucose metabolism and insulin secretion in man. J Clin Endocrinol Metab 55: 973-982

4. Rizza R, Mandarino LW, Gerich JE (1982) Effects of growth hormone on insulin action in man. Diabetes 31: 663-669

5. Press M, Tamborlane MW, Sherwin RS (1984) Importance of raised growth hormone levels in mediating the metabolic derangements of diabetes. N Engl J Med 310: 810-815

6. Adamson U, Wahren J, Cerasi E (1977) Influence of growth hormone on splanchnic glucose production in man. Acta Endocrinol 86: 803-812

7. MacGorman LR, Rizza RA, Gerich JE (1981) Physiological concentrations of growth hormone exert insulin-like and insulin antagonistic effects on both hepatic and extrahepatic tissues in man. J Clin Endocrinol Metab 53: 556-559

8. Rabinowitz D, Klassen GA, Zierler KL (1965) Effect of human growth hormone on muscle and adipose tissue metabolism in the forearm of man. J Clin Invest 44: 51-61

9. Fineberg SE, Merimee TJ (1974) Acute metabolic effects of human growth hormone. Diabetes 23: 499-504

10. Sherwin RS, Schulman GA, Hendler R, Walesky M, Belous A, Tamborlane W (1983) Effect of growth hormone on oral glucose tolerance and circulating metabolic fuels in man. Diabetologia 24: 155-161

11. Keller U, Schell H, Girard J, Stauffacher W (1984) Effect of physiological elevation of plasma growth hormone levels on ketone body kinetics and lipolysis in normal and acutely insulin-deficient man. Diabetologia 26: 103-108

12. Coles DR, Cooper KE, Mottram RF, Occleshaw JV (1958) The source of blood samples withdrawn from deep forearm veins via catheters passed upstreams from the median cubital vein. J Physiol 142: $323-328$

13. Wahren J (1966) Quantitative aspects of blood flow and oxygen uptake in the human forearm during rhythmic exercise. Acta Physiol Scand 67 [Suppl 269]: 1-93

14. Abumrad NN, Rabin ND, Diamond MP, Lacy WW (1981) Use of a heated superficial hand vein as an alternative site for the measurement of amino acid concentrations and for the study of glucose and alanine kinetics in man. Metab Clin Exp 30: 936-940

15. Whitney RJ (1953) The measurement of volume changes in human limbs. J Physiol 121: 1-27

16. Cooper KE, Edholm OG, Mottram RF (1955) The blood flow in skin and muscle of the human forearm. J Physiol 128: 258-267

17. Dillon R (1965) Importance of hematocrit in interpretation of blood sugar. Diabetes 14: 672-678

18. Newsholme EA, Leech AR (1983) Biochemistry for the medical sciences. Wiley, New York

19. DeFronzo RA, Tobin JD, Andres R (1979) Glucose clamp technique: a method for quantifying insulin secretion and insulin resistance. Am J Physiol 237: E214-E224

20. Rosenfeld RG, Wilson DM, Dollar LA, Bennett A, Hintz RL (1982) Both human pituitary growth hormone and recombinant DNA-derived human growth hormone cause insulin resistance at a postreceptor site. J Clin Endocrinol Metab 54: 1033-1038 
21. Lloyd B, Burrin J, Smythe P, Alberti KGMM (1978) A simple automated fluorimetric assay for blood glucose, lactate, pyruvate, alanine, glycerol and 3-hydroxybutyrate. Clin Chem 24: 1724-1729

22. Knor DP, Jones DG (1984) Automated enzymatic determination of plasma free fatty acids by centrifugal analysis. $\mathrm{J}$ Autom Chem 6: $152-154$

23. Hartog M, Gafaar MA, Meisser B, Frazer R (1964) Immunoassay of serum growth hormone in acromegalic patients. Br Med $\mathrm{J}$, pp 1229-1232

24. Heding LG (1972) Determination of total serum insulin (IRI) in insulin treated diabetic patients. Diabetologia 8: 260-266

25. Heding LG (1975) Radioimmunological determination of human C-peptide in serum. Diabetologia 11: 541-548

26. Kruszynska YT, Home PD, Alberti KGMM (1985) Comparison of portal and peripheral insulin delivery on carbohydrate metabolism in streptozotocin diabetic rats. Diabetologia 28: 167-171

27. Cherrington AD, Chiasson JL, Liljenquist JE, Jennings AS, Keller U, Lacy WW (1976) The role of insulin and glucagon in the regulation of basal glucose production in the postabsorbtive dog. J Clin Invest 58: 1407-1418

28. Steele R (1959) Influence of glucose loading and of injected insulin on hepatic glucose output. Ann NY Acad Sci 82: 420

29. Parker DC, Rossman LG, Kripke DF, Gibson W, Wilson K (1979) In: Krieger DT (ed) Endocrine Rhythms. Raven Press, New York, pp 143-175
30. Guler HP, Zapf J, Froesch ER (1987) Short-term metabolic effects of recombinant human insulin-like growth factor 1 in healthy adults. N Engl J Med 317: 137-140

31. DeFronzo RA, Jacot E, Jequier E, Maeder E, Wahren J, Felber JP (1981) The effect of insulin on the disposal of intravenous glucose. Results from indirect calorimetry and hepatic and femoral venous catherization. Diabetes 30: 1000-1007

32. Ferrannini E, Smith JD, Cobelli C, Toffolo G, Pilo A, DeFronzo RA (1985) Effect of insulin on the distribution and disposition of glucose in man. J Clin Invest 76:357-364

33. Bogardus C, Lillioja S, Stone K, Mott D (1984) Correlation between muscle glycogen synthase activity and in vivo insulin action in man. J Clin Invest 73: 1185-1190

34. Randle PJ, Garland PB, Hales CN, Newsholme EA (1963) The glucose fatty-acid cycle: its role in insulin sensitivity and the metabolic disturbances of diabetes mellitus. Lancet I: 785-789

Received: 8 August 1988

and in revised form: 8 December 1988

Dr. N. Møller

2nd University Clinic of Medicine

Aarhus Kommunehospital

DK-6000 Aarhus C

Denmark 